\title{
Synergistic Effect of Vitamin $C$ with Cisplatin for Inhibiting Proliferation of Gastric Cancer Cells
}

\author{
Ghazaleh Ghavami and Soroush Sardari ${ }^{*}$ \\ Drug Design and Bioinformatics Unit, Medical Biotechnology Department, \\ Biotechnology Research Center, Pasteur Institute of Iran, Tehran, Iran
}

Received 4 December 2018; accepted 5 January 2019; published online 29 October 2019

\begin{abstract}
Background: Ascorbic acid, known as vitamin C, has been used in combination with a number of cytotoxic agents in vitro and in vivo with contradictory results on its effectiveness. It is believed that vitamin $C$ can sensitize different cancer cells to common therapy strategies such as chemotherapy and radiotherapy. During current research, the combination effect of vitamin $\mathrm{C}$ with cisplatin was evaluated against gastric cancer cells. Methods: MTT-based proliferation assay, $\mathrm{Cl}$ method, and flow cytometry technique were employed for the assessment of cell cycle and determination of apoptosis/necrosis on the AGS cell line. Results: Co-treatment of gastric cancer cells with vitamin $C$ in its $I_{50}$ dose in addition to cisplatin in both $I_{50}(10 \mu \mathrm{g} / \mathrm{ml})$ and five times less $(2 \mu \mathrm{g} / \mathrm{ml})$ doses could increase the cytotoxicity effect of cisplatin in a synergistic manner. Moreover, the pointed co-treatment approach could induce the cell count in sub-G0 phase while reducing it in the G0/G1, G2/M, and S phases. Further findings showed that the combined dose of vitamin $\mathrm{C}$ and cisplatin could increase the percentage of apoptotic and necrotic cells in comparison with a single dose of cisplatin. Conclusion: This study introduces a possible approach for the treatment of gastric cancer with more potency and less amount of administered cisplatin to induce toxicity. DOI: 10.29252/ibj.24.2.119
\end{abstract}

Keywords: Ascorbic acid, Cisplatin, Neoplasms

Corresponding Author: Soroush Sardari

Drug Design and Bioinformatics Unit, Medical Biotechnology Department, Biotechnology Research Center, Pasteur Institute of Iran, Tehran, Iran; Tel.: (+98-216) 6954324; E-mail: ssardari@hotmail.com

\section{INTRODUCTION}

A scorbic acid, commonly known as vitamin C, is utilized as one of the most important dietary supplements and safe medicines in the health system based on the reports of World Health Organization's Model List of Essential Medicines ${ }^{[1]}$. This vital antioxidant supplement plays critical roles in the process of repairing tissues, producing neurotransmitters through enzymatic mechanisms, and modulating of immune system. It is also known as the most powerful radical scavenger agent $t^{[1,2]}$.

Herbs containing vitamin $\mathrm{C}$ have been reported to be from families of Rutaceae (Citrus sp.), Actinidiaceae (Actinidia sp.), Brassicaceae (Brassica sp.), Solanaceae
(Capsicum sp.), Rosaceae (Fragaria sp. $)^{[1]}$, Moraceae (Morus sp., specially Morus nigra and Morus alba), Musaceae (Musa sp., particularly Musa paradisiaca and Musa sapientum $)^{[3-5]}$.

Findings show that vitamin $\mathrm{C}$, as one of the first major defense systems against aqueous radicals in blood, can have a critical role in protecting biological membranes against primary peroxidative damages. In addition, it has ability to reduce oxygen, nitrogen, and sulfur radicals in its non-toxic doses ${ }^{[2]}$. In fact, vitamin $\mathrm{C}$ can reduce nitrate and prevent the generation process of carcinogenic nitrosamines by employing NADHdependent system ${ }^{[2]}$.

The growth inhibitory properties of vitamin $\mathrm{C}$ and its derivatives in more than seven varieties of cancer cells 
without inducing cytotoxic effects on normal fibroblast cells have previously been indicated ${ }^{[2]}$. It has also been demonstrated that the cytotoxic effect of vitamin $\mathrm{C}$ on a set of malignant cell lines is commonly related to its pro-oxidant property, which leads to the activation of transcription factor NF-kappa B and finally, the cell growth inhibition $^{[2]}$. Furthermore, with generating hydrogen peroxide and activating hydroxyl radical, vitamin $\mathrm{C}$ can reduce cell replication mechanism as well as tumor cell viability via inducing DNA strand breakage, controlling mitotic activity, and damaging the mitochondria and cell membranes. Vitamin $\mathrm{C}$ has also been found to act as an anticancer agent by reduction in hypoxia-inducible factor 1, causing reductive energy, i.e. vitamin $\mathrm{C}$ can induce tumor cell death via stabilizing $\mathrm{p} 53$, as a main protein involved in controlling cell proliferation ${ }^{[2]}$. Reported data have suggested that the administration of vitamin $\mathrm{C}$ alone can induce toxicity on AGS cell line through the activation of caspase cascades and the related apoptotic pathway. This activation may occur by inducing calcium efflux from endoplasmic reticulum, generating reactive oxygen species, reducing adenosine triphosphate production, and stimulating autophagy pathway $^{[6,7]}$.

Further relevant studies have revealed that combining vitamin $\mathrm{C}$ with 5-fluorouracil, sodium dascorbate, cyclophosphamide, paclitaxel, arsenic trioxide, doxorubicin, and radiation can sensitize the cancer cells to the exposed anticancer drugs and enhance the success rate of hemo/radiotherapy ${ }^{[8,9]}$. Indeed, the clinical evaluation confirmed the major positive effect of vitamin $\mathrm{C}$ on enhancing the quality of life in 30-95\% of cancer patients during chemo/radiotherapy procedures ${ }^{[9]}$.

The current investigation was attempted to study the combination treatment effect of vitamin $\mathrm{C}$ with cisplatin on gastric cancer cells, in order to introduce a new possible treatment strategy of gastric cancer with more efficacy parallel to the reduction of cisplatin side effects.

\section{MATERIALS AND METHODS}

\section{Cell culture}

Human gastric adenocarcinoma (AGS) cell line (IBRC C10071) was purchased from Iranian Biological Resource Center (Tehran, Iran) and cultured in RPMI 1640 (Biosera, France) with 10\% fetal bovine serum and $2 \mathrm{~g} / \mathrm{l}$ of HEPES buffer (both from Biosera) in 5\% $\mathrm{CO}_{2}$ at $37{ }^{\circ} \mathrm{C}$. The cells with $80 \%$ confluency were passaged by Trypsin-EDTA solution $1 \times$ (Biosera). The 96- and 24-multiwell plates were used to perform MTT and cell cycle/apoptosis tests for seeding the cells at a density of $10^{4}$ cells $/ \mathrm{cm}^{2}$ and $10^{5}$ cells $/ \mathrm{cm}^{2}$, respectively.

\section{Cell proliferation assay}

AGS cells were seeded on 96-well plates, and the medium was replaced with serum-free RPMI 1640 medium containing vitamin $\mathrm{C}$ (Sigma-Aldrich, Germany) in $8,40,200$, and $1000 \mu \mathrm{g} / \mathrm{ml}$ and cisplatin (Mylan, Netherlands) in 0.8, 4, 20, 100, and $500 \mu \mathrm{g} / \mathrm{ml}$ doses as the positive control. Serum-free RPMI 1640 medium was used as the solvent and negative control. The treatment process was performed in $5 \% \mathrm{CO}_{2}$ at $37{ }^{\circ} \mathrm{C}$ for 48 hours. After the treatment, each well received $20 \mu \mathrm{l}$ of MTT dye $(0.5 \mathrm{mg} / \mathrm{mL}$; SigmaAldrich) was added to each well, and the plate was incubated at $37{ }^{\circ} \mathrm{C}$ for 4 hours. Subsequently, the treatment medium was replaced by DMSO (Fluka, USA). After $30 \mathrm{~min}$, the absorbance level of each well was measured with a multi-well scanning spectrophotometer (ELISA reader, Organon Tekninka, Netherlands) at the wavelength of $545 \mathrm{~nm}$. The results were calculated as cell toxicity rate $=1-(\mathrm{OD}$ of the sample well-OD of the blank well $) /(\mathrm{OD}$ of control well-OD of blank well) $\times 100 \%{ }^{[10]}$. All the measurements were conducted in triplicates.

\section{Assessment of the cell cycle progression}

For cell cycle analyses, AGS cells $\left(1.0 \times 10^{5}\right.$ cells $/ \mathrm{cm}^{2}$ ) were treated with vitamin $\mathrm{C}$ alone and in combination with cisplatin for 48 hour. The treated cells were then fixed with $70 \%$ ethanol in cold room for 5 hour and then stained with $0.1 \%$ Triton X-100 (Sigma-Aldrich), $0.5 \mathrm{mg} / \mathrm{ml}$ of ribonuclease A (Sinaclon, Iran), and $0.025 \mathrm{mg} / \mathrm{ml}$ of PI (SigmaAldrich) at room temperature for $30 \mathrm{~min}$ before flow cytometry by CyFlow (Partec, Germany) ${ }^{[11]}$.

\section{Apoptosis and necrosis detection}

The rate of apoptosis was investigated by annexin- $\mathrm{V}$ and PI double staining ${ }^{[12]}$. After the treatment of AGS cells $\left(1.0 \times 10^{5}\right.$ cells $\left./ \mathrm{cm}^{2}\right)$ by vitamin $\mathrm{C}$ alone and in combination with cisplatin for 48 hour, the cells were pooled and centrifuged at $112 \mathrm{RCF}$ at $4{ }^{\circ} \mathrm{C}$ for $5 \mathrm{~min}$. Next, the treated cells were stained with annexin Vfluorescein isothiocyanate and PI (IQ Products BV, Netherlands) based on the manufacturer's procedure and analyzed by a flow cytometer (CyFlow).

\section{Statistical analysis}

Entire tests were performed as triplicate tests $(n=3)$, and relevant results were analyzed by Graph Pad Prism 5.0 software (GraphPad, La Jolla, CA, USA) to calculate $\mathrm{IC}_{50} \mathrm{~S}$ (regression equation with the 95\% confidence interval) and mean \pm SEM. Statistical comparisons were conducted by ANOVA and post hoc 

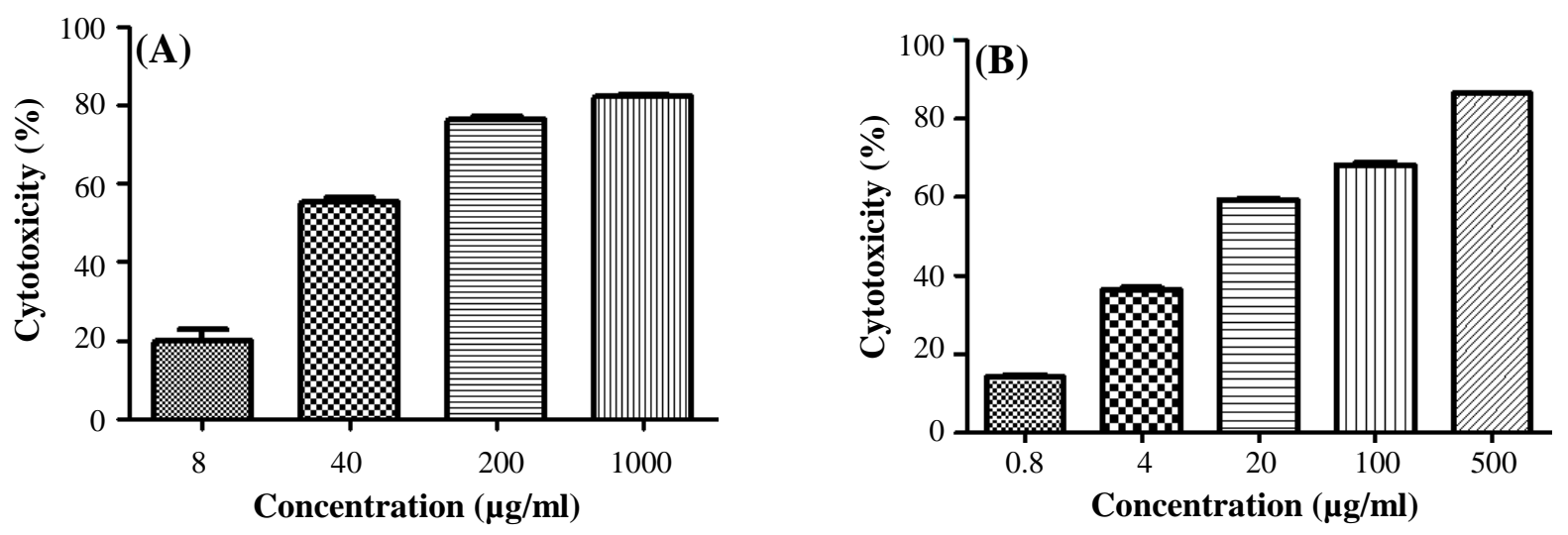

Fig. 1. The cytotoxic effects of (A) vitamin C $(49.38 \pm 0.82 \mu \mathrm{g} / \mathrm{ml})$ and (B) cisplatin $(10.58 \pm 0.49 \mu \mathrm{g} / \mathrm{ml})$ alone on AGS cell line. Data are shown as mean \pm SEM. Statistical comparison with solvent $(p<0.05)$ was calculated for vitamin C and cisplatin as $p<0.001$.

Tukey's test utilizing Graph Pad Prism 4.0 and Statistical 6.0 program. The differences were considered as statistically significant when $p<0.05$. CI method was employed to evaluate the interaction between vitamin $\mathrm{C}$ and cisplatin. CI was presented by ComboSyn (ComboSyn Inc., NY, USA) as the CI theorem of Chou-Talalay, which is a quantitative assessment of expressions of synergism $(\mathrm{CI}<1)$, additive $(\mathrm{CI}=1)$, and antagonism $(\mathrm{CI}>1)$.

\section{RESULTS}

\section{Cell proliferation assay}

MTT assay was performed to study the cytotoxic properties of vitamin $\mathrm{C}$ alone (Fig. 1) and in combination with cisplatin (Fig. 2 and Table 1) on AGS cell line. In dose of $49.38 \pm 0.82 \mu \mathrm{g} / \mathrm{ml}$, vitamin $\mathrm{C}$ showed cytotoxic effect on AGS cells. Evaluating the combined cytotoxic effects of vitamin $\mathrm{C}$ with cisplatin on gastric cancer cell line was carried out based on CI theorem of Chou-Talalay. Treatment of AGS cells with the combined dose of vitamin $\mathrm{C}$ and cisplatin was led to higher in vitro cytotoxic effect of cisplatin against gastric cancer cells in both $\mathrm{IC}_{50}$ and five times less than $\mathrm{IC}_{50}$ doses in a synergistic manner with CIs $<1$

\section{Cell cycle progression assay}

In order to determine the DNA count in each cell cycle stage for the AGS cells treated by vitamin C alone and in combination with cisplatin (Fig. 3), PI staining was employed and the results were compared (Fig. 4) based on $p$ value calculation (Table 2). Vitamin $\mathrm{C}$ alone and in combination with cisplatin ( 2 and $10 \mu \mathrm{g} / \mathrm{ml}$ ) could increase the cell count in the sub-G0 phase, but the single dose of vitamin C could decrease the cell count in the G0/G1 phase, as compared to the RPMI control group $(p<0.05)$. Meanwhile, vitamin $\mathrm{C}$ in combination with cisplatin
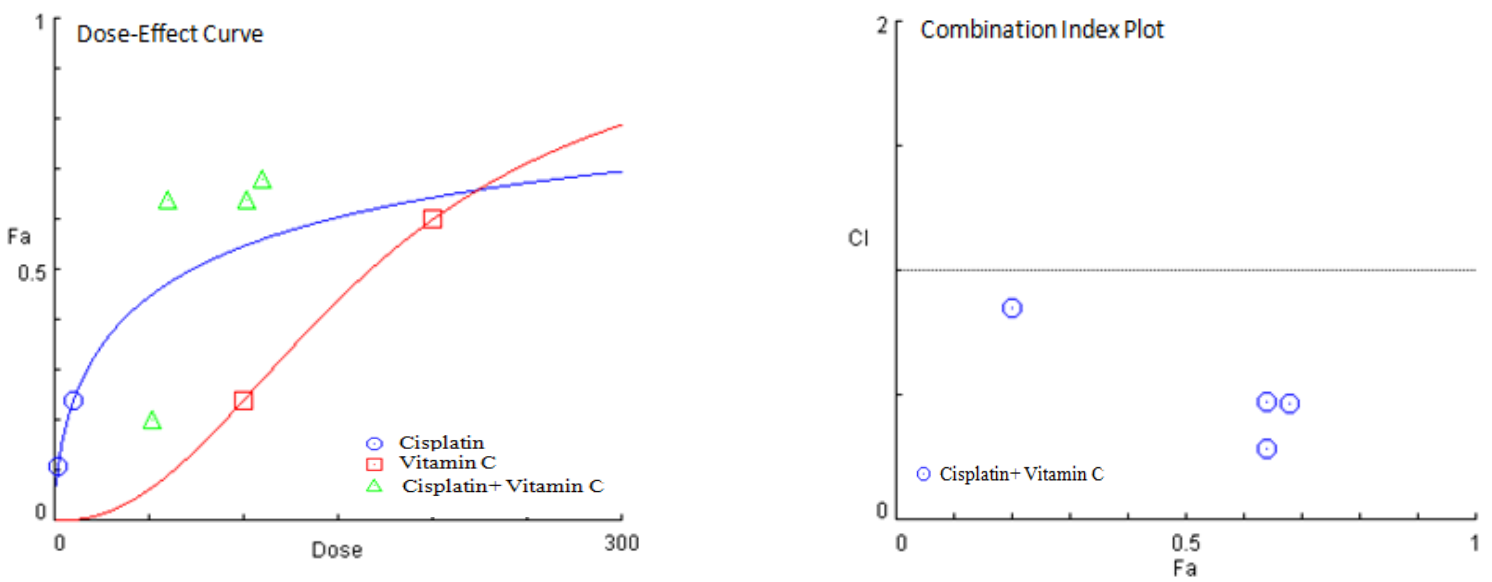

Fig. 2. CI method for the assessment of the combination effects of vitamin $\mathrm{C}$ with cisplatin on gastric cancer cells. CI plot presents $\mathrm{CI}$ at different ratios of the Fa. Calculated data demonstrated the synergism $(\mathrm{CI}<1)$ between vitamin $\mathrm{C}$ and cisplatin. 
Table 1. Combination cytotoxic effects of vitamin $\mathrm{C}$ with cisplatin on AGS cell line based on the calculation of $\mathrm{CI}$ and $\mathrm{Fa}$

\begin{tabular}{lcccc}
\hline Samples & $\begin{array}{c}\text { Vitamin C } \\
\text { dose }(\boldsymbol{\mu g} / \mathbf{m l})\end{array}$ & $\begin{array}{c}\text { Cisplatin } \\
\text { dose }(\boldsymbol{\mu g} / \mathbf{m l})\end{array}$ & CI & Fa \\
\hline \multirow{3}{*}{ Vitamin C + cisplatin } & 100 & 10 & 0.46620 & 0.68 \\
& 50 & 10 & 0.28337 & 0.64 \\
& 100 & 2 & 0.47392 & 0.64 \\
& 50 & 2 & 0.85337 & 0.20 \\
\hline
\end{tabular}
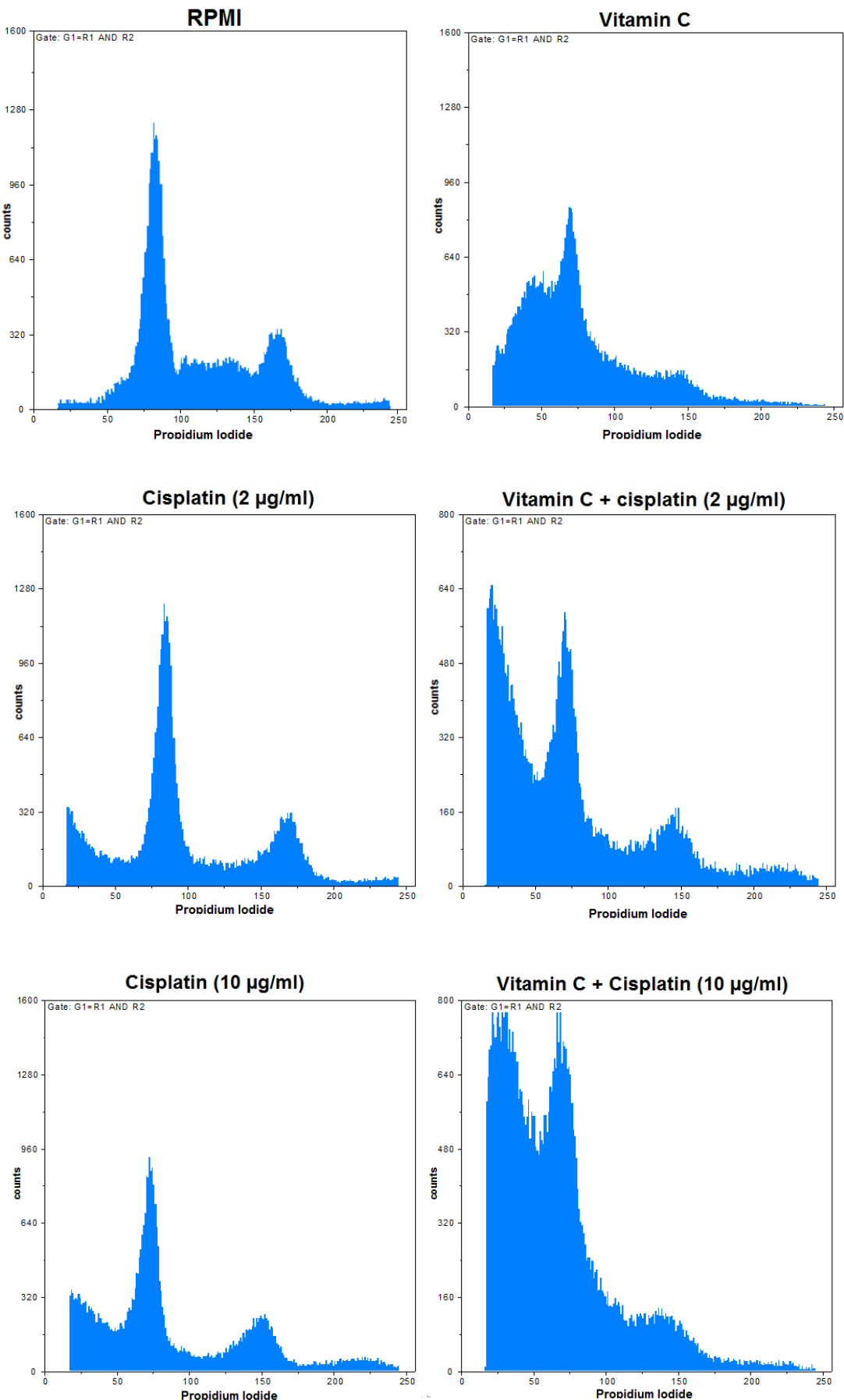

Fig. 3. Effects of vitamin $\mathrm{C}$ and cisplatin alone and vitamin $\mathrm{C}+$ cisplatin treatments on cell cycle distribution of gastric cancer cells. RPMI 1640 was used as the negative control. 


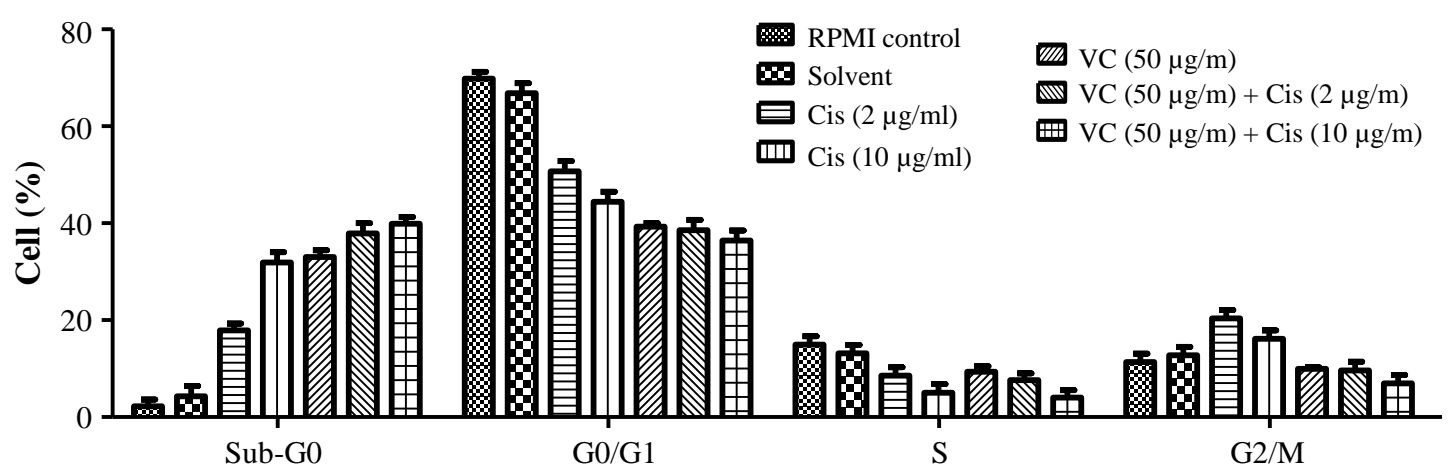

Fig. 4. Comparison of vitamin C (VC) and cisplatin (Cis) properties on cell cycle distribution of AGS cells. Data are shown with SD.

( 2 and $10 \mu \mathrm{g} / \mathrm{ml}$ ) could decrease the cell count in both G0/G1 and S phases in comparison with RPMI control group $(p<0.05)$. Furthermore, single and combined doses of vitamin $\mathrm{C}$ with cisplatin $(2$ and $10 \mu \mathrm{g} / \mathrm{ml})$ could decrease in $\mathrm{G} 2 / \mathrm{M}$ phase in comparison with cisplatin in single doses $(p<0.05)$. Vitamin C (50 $\mu \mathrm{g} / \mathrm{ml})$ plus cisplatin $(2$ and $10 \mu \mathrm{g} / \mathrm{ml})$ in combination doses could decrease significantly $(p<0.05)$ the cell count in G0/G1 phase in comparison with the single dose of cisplatin $(2 \mu \mathrm{g} / \mathrm{ml})$. Indeed, vitamin C (50 $\mu \mathrm{g} / \mathrm{ml})$ plus cisplatin $(10 \mu \mathrm{g} / \mathrm{ml})$ in combination dose could decrease cell count in G0/G1 in comparison with both single doses of cisplatin ( 2 and $10 \mu \mathrm{g} / \mathrm{ml} ; p<$ $0.05)$. These data clarified that the pointed combination treatments of vitamin $\mathrm{C}$ and cisplatin could induce cell deaths in AGS cells in comparison with the single doses of cisplatin and control groups.

\section{Apoptosis and necrosis detection}

To study whether the cytotoxicity effects of vitamin $\mathrm{C}$, cisplatin, and vitamin C plus cisplatin on AGS cells were due to the induction of apoptosis, necrosis, or both of them (Fig. 5), the annexin-V and PI double staining method was employed and the results were compared (Fig. 6) based on $p$ value calculation (Table $3)$. As shown in Figure 6, treatment of cells with vitamin $\mathrm{C}$ in single dose $(50 \mu \mathrm{g} / \mathrm{ml})$ led to decreasing alive and increasing early apoptotic cell counts compared with cisplatin $(2 \mu \mathrm{g} / \mathrm{ml} ; p<0.05)$. Besides, vitamin $C$ in single dose $(50 \mu \mathrm{g} / \mathrm{ml})$ could decrease cell count in late apoptotic and necrotic phases. Furthermore, vitamin C in the single dose of $100 \mu \mathrm{g} / \mathrm{ml}$ could decrease significantly $(p<0.05)$ the alive and increase early and late apoptotic cell counts compared with cisplatin of $2 \mu \mathrm{g} / \mathrm{ml}$. Using vitamin $C$ in single

Table 2. Effects of vitamin C (VC) and cisplatin (Cis) alone and in combination on cell cycle of AGS cells

\begin{tabular}{|c|c|c|c|c|c|c|c|c|c|c|}
\hline \multirow{2}{*}{ Sample } & \multirow{2}{*}{ Controls } & \multicolumn{4}{|c|}{ Cell cycle (\% cells) } & \multirow{2}{*}{$\begin{array}{c}\text { Cisplatin } \\
(\mu \mathrm{g} / \mathrm{ml})\end{array}$} & \multicolumn{4}{|c|}{ Cell cycle (\% cells) } \\
\hline & & Sub G0 & G0/G1 & $\mathbf{S}$ & G2/M & & Sub G0 & G0/G1 & $\mathbf{S}$ & G2/M \\
\hline \multirow{4}{*}{$\mathrm{VC}(50 \mu \mathrm{g} / \mathrm{ml})$} & RPMI & $p<0.001$ & $p<0.001$ & Ns & Ns & \multirow{2}{*}{2} & $p<0.001$ & $p<0.001$ & Ns & $p<0.001$ \\
\hline & control & $\uparrow$ & $\downarrow$ & $\downarrow$ & $\downarrow$ & & $\uparrow$ & $\downarrow$ & $\uparrow$ & $\downarrow$ \\
\hline & Solvent & $p<0.001$ & $p<0.001$ & Ns & Ns & \multirow{2}{*}{10} & $p<0.05$ & Ns & Ns & $p<0.05$ \\
\hline & control & $\uparrow$ & $\downarrow$ & $\downarrow$ & $\downarrow$ & & $\uparrow$ & $\downarrow$ & $\uparrow$ & $\downarrow$ \\
\hline \multirow{4}{*}{$\begin{array}{c}\mathrm{VC}(50 \mu \mathrm{g} / \mathrm{ml}) \\
+ \\
\text { Cis }(2 \mu \mathrm{g} / \mathrm{ml})\end{array}$} & RPMI & $p<0.001$ & $p<0.001$ & $p<0.01$ & Ns & \multirow{2}{*}{2} & $p<0.001$ & $p<0.001$ & Ns & $p<0.001$ \\
\hline & control & $\uparrow$ & $\downarrow$ & $\downarrow$ & $\downarrow$ & & $\uparrow$ & $\downarrow$ & $\downarrow$ & $\downarrow$ \\
\hline & Solvent & $p<0.001$ & $p<0.001$ & Ns & Ns & \multirow{2}{*}{10} & $p<0.01$ & Ns & Ns & $p<0.05$ \\
\hline & control & $\uparrow$ & $\downarrow$ & $\downarrow$ & $\downarrow$ & & $\uparrow$ & $\downarrow$ & $\uparrow$ & $\downarrow$ \\
\hline \multirow{4}{*}{$\begin{array}{c}\mathrm{VC}(50 \mu \mathrm{g} / \mathrm{ml}) \\
+ \\
\text { Cis }(10 \mu \mathrm{g} / \mathrm{ml})\end{array}$} & RPMI & $p<0.001$ & $p<0.001$ & $p<0.001$ & Ns & \multirow{2}{*}{2} & $p<0.001$ & $p<0.001$ & Ns & $p<0.001$ \\
\hline & control & $\uparrow$ & $\downarrow$ & $\downarrow$ & $\downarrow$ & & $\uparrow$ & $\downarrow$ & $\downarrow$ & $\downarrow$ \\
\hline & Solvent & $p<0.001$ & $p<0.001$ & $p<0.001$ & Ns & \multirow{2}{*}{10} & $p<0.001$ & $p<0.05$ & Ns & $p<0.01$ \\
\hline & control & $\uparrow$ & $\downarrow$ & $\downarrow$ & $\downarrow$ & & $\uparrow$ & $\downarrow$ & $\downarrow$ & $\downarrow$ \\
\hline
\end{tabular}

Ns, non-significant difference $(p>0.05)$; $\downarrow$ decreasing and $\uparrow$ increasing cell percentage in the cell cycle phases because of cell treatments by samples in comparison with controls and Cis 

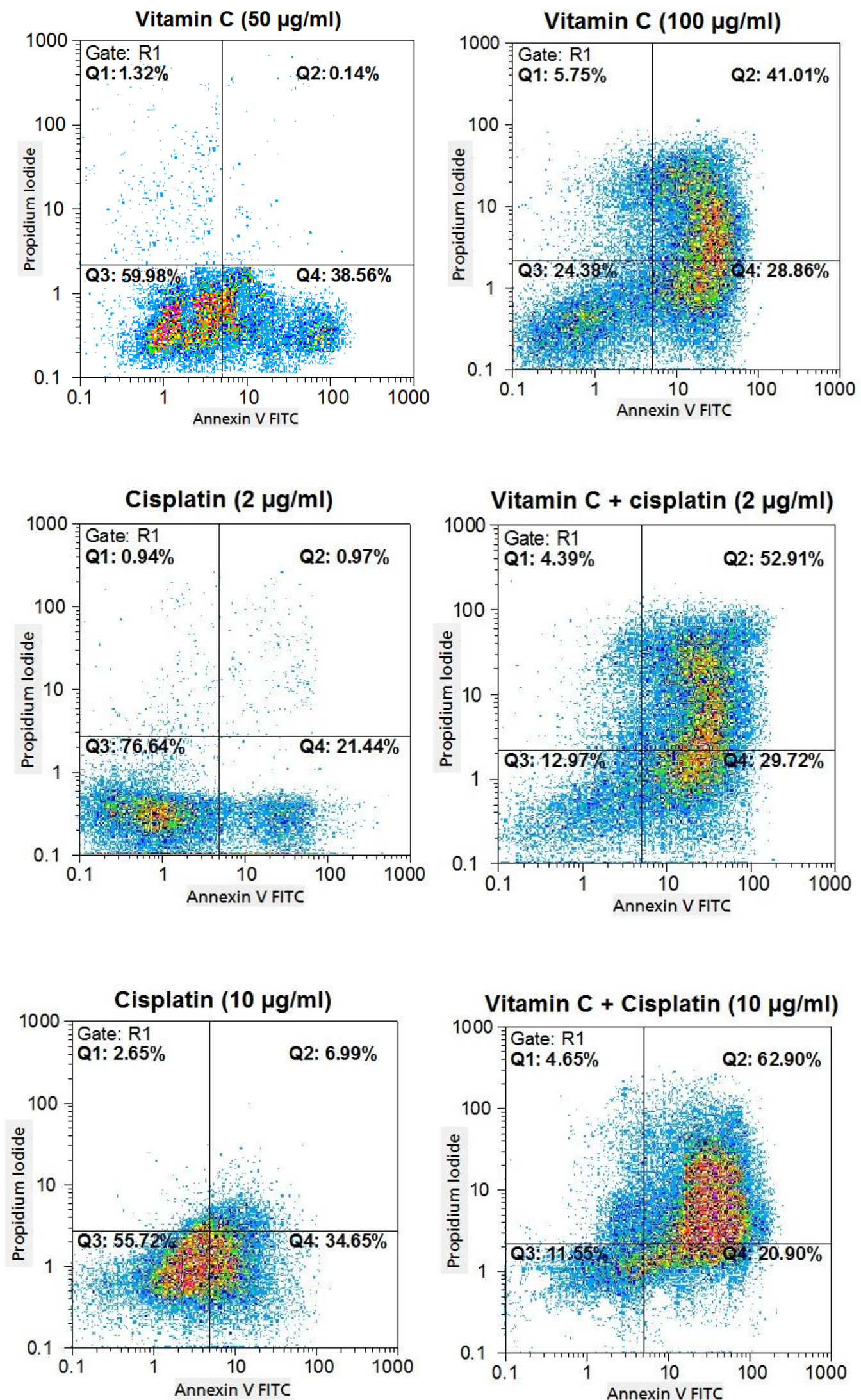

Fig. 5. The percentages of apoptotic- and necrotic-treated AGS cells with vitamin C, cisplatin, and vitamin C plus cisplatin, shown in flow cytometry dot plots. 


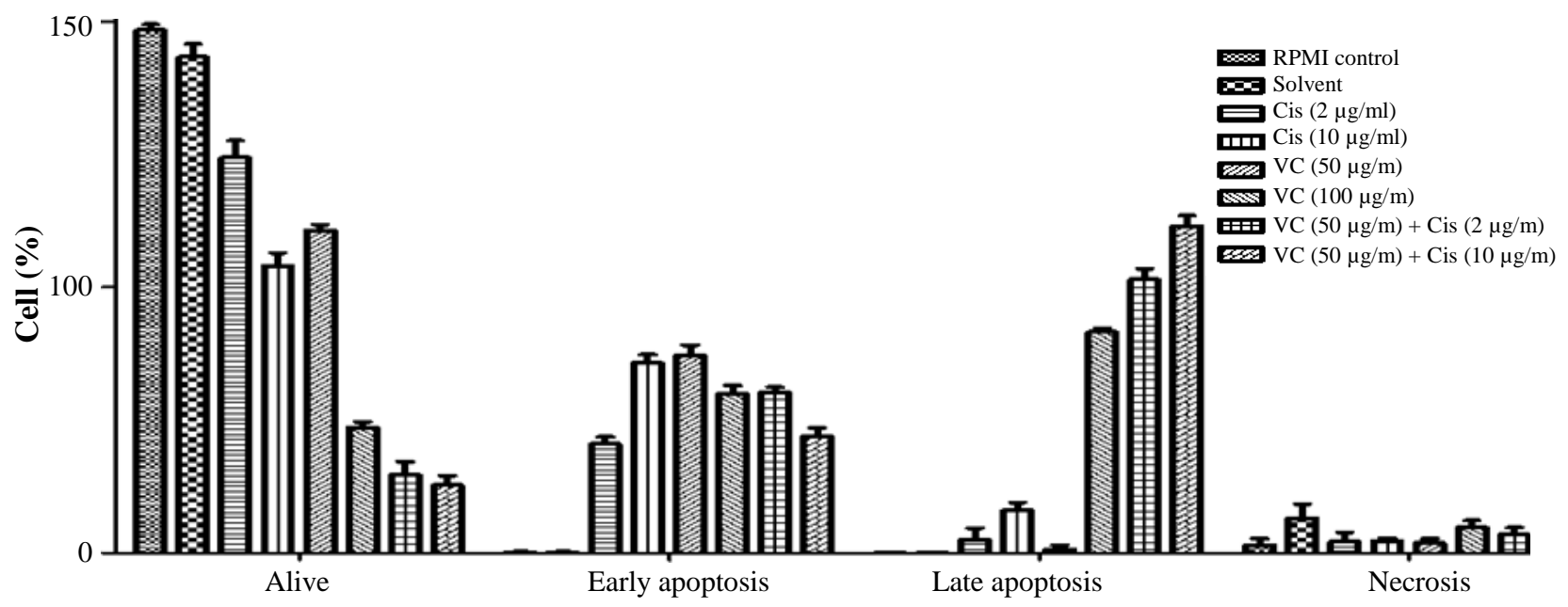

Fig. 6. Comparison of cytotoxicity effects of vitamin C (VC) and cisplatin (Cis) properties on cell cycle distribution of AGS cells, data shown with SD.

dose $(100 \mu \mathrm{g} / \mathrm{ml})$ led to significant $(p<0.05)$ decrease in alive and early apoptotic and increase in late apoptotic cell counts compared with cisplatin (10 $\mu \mathrm{g} / \mathrm{ml})$. Finally, the data showed that vitamin C (50 $\mu \mathrm{g} / \mathrm{ml}$ ) plus cisplatin (2 and $10 \mu \mathrm{g} / \mathrm{ml}$ ) in combination manner could reduce alive and induce early and late apoptotic cell counts compared with $2 \mu \mathrm{g} / \mathrm{ml}$ single dose of cisplatin, but in comparison with $10 \mu \mathrm{g} / \mathrm{ml}$ single dose of cisplatin, it decreased and induced early and late apoptotic cell counts, respectively $(p<0.05)$.

\section{DISCUSSION}

Cancer and its treatment approaches are the most serious health challenges, and World Health Organization relevant report has estimated that the rate of cancer (the number of new cases of cancer) will be more than 15 million per year in 2020. Nowadays, in spite of the introduction of a wide range of innovative cancer therapy approaches, the chemotherapy-based methods are efficient and common treatment strategies alone and in parallel with surgery and radiotherapy ${ }^{[8]}$.

Cisplatin has been renowned as an anticancer drug with wide usage for chemotherapy of different tumors such as testicular, head and neck, ovarian, cervical, non-small cell lung, and gastric carcinoma. The major mechanism of cytotoxic action of cisplatin is related to its reaction with inter- and intra-strands DNA, and formation of covalent cisplatin-DNA adducts. Formation of cisplatin-DNA adduct leads to a series of enzymatic cascades in nucleus, cytosol, and cell surface in addition to immune responses, which these enzymatic cascades and molecular responses cause cell death. These nonspecific cytotoxic effects of cisplatin imposes wide ranges of side effects on kidney and liver as well as nervous and hearing systems and induce undesirable drug resistance phenomenon $^{[8]}$. To overcome the adverse effects caused by the administration of cisplatin, some combination treatment strategies have been used such as prescribing of cisplatin in combination with WR2721, quercetin, and cordycepin ${ }^{[8]}$. Additionally, the previous study carried out by our research group showed that herbal extract, including Morus alba, Musa sapientum, Arnebia decumbens, Arnebia echioides, and Arnebia linearifolia DC could induce the toxicity effect of cisplatin against A2780/cp (human ovarian carcinoma/resistant to cisplatin) cells in parallel with the reduction of its toxicity on HF2 (normal human fetal fibroblast) cell line ${ }^{[13]}$. Evidence has also suggested the anticancer activity of vitamin $\mathrm{C}$ against a variety of cancer cell lines ${ }^{[2]}$. The current investigation was carried out to examine the efficiency of vitamin $\mathrm{C}$ in the reduction of the toxicity exposed by cisplatin. Previous investigations have observed that the therapeutic effectiveness of cisplatin was more favorable with vitamin $\mathrm{C}$ than its single use $^{[8]}$. In addition, vitamin $C$ could reduce the systemic toxicity of cisplatin in the mice model, especially with protecting kidney and liver in addition to sperms against cisplatin-induced toxicity and abnormality based on the reduction of glutathione level and induction of lipid peroxidation reactions ${ }^{[14]}$. A similar study has also identified that vitamin $\mathrm{C}$ could decrease nephrotoxicity caused by cisplatin without reduction in the efficacy of cisplatin in C57BL/6 mice with Lewis lung carcinoma ${ }^{[15]}$. Additional studies have demonstrated that the co-administration of vitamin $\mathrm{C}$ and cisplatin could protect kidney and normal cells against cisplatin-induced nephrotoxicity and genotoxicity in vivo ${ }^{[15-17]}$ 
Table 3. Comparison of vitamin $\mathrm{C}(\mathrm{VC})$ and cisplatin (Cis) properties on inducing apoptosis/necrosis

\begin{tabular}{|c|c|c|c|c|c|}
\hline \multirow[b]{2}{*}{ Sample } & \multirow{2}{*}{$\begin{array}{c}\text { Cisplatin } \\
(\mu \mathrm{g} / \mathrm{ml})\end{array}$} & \multicolumn{4}{|c|}{ Cell percentage } \\
\hline & & Alive & $\begin{array}{c}\text { Early } \\
\text { apoptosis }\end{array}$ & $\begin{array}{c}\text { Late } \\
\text { apoptosis }\end{array}$ & Necrosis \\
\hline \multirow[b]{2}{*}{$\mathrm{VC}(50 \mu \mathrm{g} / \mathrm{ml})$} & 2 & $\begin{array}{c}p<0.001 \\
\downarrow\end{array}$ & $\begin{array}{c}p<0.001 \\
\uparrow\end{array}$ & $\underset{\downarrow s}{\mathrm{Ns}}$ & $\underset{\downarrow}{\mathrm{Ns}}$ \\
\hline & 10 & $\begin{array}{l}\mathrm{Ns} \\
\uparrow\end{array}$ & $\begin{array}{l}\mathrm{Ns} \\
\uparrow\end{array}$ & $\begin{array}{c}p<0.01 \\
\downarrow\end{array}$ & $p<\underset{\downarrow}{0.01}$ \\
\hline \multirow{2}{*}{$\mathrm{VC}(100 \mu \mathrm{g} / \mathrm{ml})$} & 2 & $p<\underset{\downarrow}{0.001}$ & $\begin{array}{c}p<0.001 \\
\uparrow\end{array}$ & $\underset{\substack{\uparrow \\
\uparrow}}{0.001}$ & $\begin{array}{c}\mathrm{Ns} \\
\uparrow\end{array}$ \\
\hline & 10 & $p<\underset{\downarrow}{0.001}$ & $p<\underset{\downarrow}{ } 0.05$ & $\underset{\substack{\uparrow \\
\uparrow}}{0.001}$ & $\underset{\uparrow}{\mathrm{Ns}}$ \\
\hline \multirow{2}{*}{$\mathrm{VC}(50 \mu \mathrm{g} / \mathrm{ml})+\mathrm{Cis}(2 \mu \mathrm{g} / \mathrm{ml})$} & 2 & $p<\underset{\downarrow}{0.001}$ & $\begin{array}{c}p<\underset{\uparrow}{0} 0.001 \\
\text {. }\end{array}$ & $\begin{array}{c}p<\underset{\uparrow}{0} \\
0.001\end{array}$ & $\underset{\uparrow}{\mathrm{Ns}}$ \\
\hline & 10 & $p<\underset{\downarrow}{0.001}$ & $p<\underset{\downarrow}{ } 0.05$ & $\underset{\uparrow}{p<} \underset{\uparrow}{0.001}$ & $\underset{\uparrow}{\mathrm{Ns}}$ \\
\hline \multirow{2}{*}{$\mathrm{VC}(50 \mu \mathrm{g} / \mathrm{ml})+\mathrm{Cis}(10 \mu \mathrm{g} / \mathrm{ml})$} & 2 & $p<\underset{\downarrow}{0.001}$ & $\begin{array}{c}p<0.05 \\
\uparrow\end{array}$ & $\underset{\substack{\uparrow \\
\uparrow}}{0.001}$ & $\begin{array}{c}\mathrm{Ns} \\
\uparrow\end{array}$ \\
\hline & 10 & $p<\underset{\downarrow}{0.001}$ & $p<0.05$ & $\begin{array}{c}p<0.001 \\
\uparrow\end{array}$ & $\begin{array}{c}\mathrm{Ns} \\
\uparrow\end{array}$ \\
\hline
\end{tabular}

Ns, non-significant difference $(p>0.05)$; $\downarrow$, decreasing and $\uparrow$ increasing alive, early apoptotic, late apoptotic and necrotic cell percentages because of cell treatments by samples in comparison with Cis

Based on previous in vitro and in vivo investigations, the current research was carried out to present potential approach against gastric cancer based on increasing the efficacy of treatment in addition to decreasing the cisplatin induced systemic toxicity such as hepatotoxicity, nephrotoxicity, and genotoxicity. The results of co-treatment of AGS cells by vitamin $\mathrm{C}$ and cisplatin confirmed the synergistic interaction between vitamin $\mathrm{C}$ and cisplatin for inducing cytotoxicity against gastric cancer cells in vitro.

The $\mathrm{IC}_{50}$ values for vitamin $\mathrm{C}(49.38 \pm 0.82 \mu \mathrm{g} / \mathrm{ml})$ and cisplatin $(10.58 \pm 0.49 \mu \mathrm{g} / \mathrm{ml})$ in single use revealed the required information for selecting optimal doses for further experiments as combination treatment-based assay, cell cycle, and apoptosis/ necrosis determination analyses. The co-treatment of AGS cells with vitamin $\mathrm{C}$ in 50 and $100 \mu \mathrm{g} / \mathrm{ml}$ doses in addition to cisplatin in 10 and $2 \mu \mathrm{g} / \mathrm{ml}$ doses showed that vitamin $\mathrm{C}$ could enhance the in vitro anticancer effect of cisplatin in both its $\mathrm{IC}_{50}$ and five times less than $\mathrm{IC}_{50}$ doses in synergistic manner with CIs $<1$.

In this study, flow cytometry-based methods were performed to determine apoptotic and necrotic cell death and also the cell cycle distribution of the treated AGS cells with vitamin $C(100 \mu \mathrm{g} / \mathrm{ml})$ and cisplatin ( 2 and $10 \mu \mathrm{g} / \mathrm{ml}$ ) alone and in combination doses (vitamin $\mathrm{C}$ in $50 \mu \mathrm{g} / \mathrm{ml}$ dose plus cisplatin in 2 and 10 $\mu \mathrm{g} / \mathrm{ml}$ doses).

The results of flow cytometry revealed that vitamin $\mathrm{C}$ alone and in combination with cisplatin in two tested doses could elevate the percentage of cells in the subG0 phase compared with cisplatin single therapy. Moreover, treatment of cells with vitamin $\mathrm{C}$ alone and in combination with cisplatin led to increasing the percentage of apoptotic and necrotic cells, as compared to the negative control and cisplatin single treatment.

Taken together, the findings of current research show that the co-administration of vitamin $\mathrm{C}$ with cisplatin may be developed as an innovative, effective therapeutic strategy for patients with gastric cancer in the future.

\section{ACKNOWLEDGEMENTS}

This research was partially funded by the Pasteur Institute of Iran (Tehran, Iran) and Deputy of Research and Technology, Ministry of Health and Medical Education of Iran (grant no. 600) in partial fulfillment of Ph.D. thesis of Ghazaleh Ghavami (the first author).

CONFLICT OF INTEREST. None declared.

\section{REFERENCES}

1. Padayatty SJ, Katz A, Wang Y, Eck P, Kwon O, Lee JH, Chen S, Corpe C, Dutta A, Dutta SK, Levine M. Vitamin $\mathrm{C}$ as an antioxidant: evaluation of its role in disease prevention. Journal of the American College of 
Nutrition 2003; 22(1): 18-35.

2. Gonzalez MJ, Miranda-Massari JR, Jorge R. New Insights on Vitamin $\mathrm{C}$ and Cancer. Londen: Springer; 2014.

3. Imran M, Khan H, Shan M, Khan R, Khan F. Chemical composition and antioxidant activity of certain Morus species. Journal of Zhejiang University Science B 2010; 11(12): 973-980.

4. Shah SM, Razzaq A, Ali U, K Basheer, Iqbal A. Evaluation of ascorbic acid and moisture contents in two Morus species of University of Peshawar Botanical Garden, Pakistan. International journal of science and technoledge 2014; 2(7): 171.

5. Imam MZ, Akter S. Musa paradisiaca L. and Musa sapientum L.: A phytochemical and pharmacological review. Journal of applied pharmaceutical science 2011; 1(5): 14-20.

6. Van der Reest J, Gottlieb E. Anti-cancer effects of vitamin C revisited. Cell research 2016; 26(3): 269-270.

7. Lim JY, Kim D, Kim BR, Jun JS, Yeom JS, Yeom JS, Park JS, Seo JH, Park CH, Woo HO, Youn HS, Baik $\mathrm{SC}$, Lee WK, Cho MJ, Rhee KH. Vitamin C induces apoptosis in AGS cells via production of ROS of mitochondria. Oncology letters 2016; 12(5): 4270-4276.

8. Longchar A, Prasad SB. Biochemical changes associated with ascorbic acid-cisplatin combination therapeutic efficacy and protective effect on cisplatininduced toxicity in tumor-bearing mice. Toxicology reports 2015; 2: 489-503.

9. Wilson MK, Baguley BC, Wall C, Jameson MB, Findlay MP. Review of high-dose intravenous vitamin C as an anticancer agent. Asia-Pacific journal of clinical oncology 2014; 10(1): 22-37.

10. Denizot F, Lang R. Rapid colorimetric assay for cell growth and survival: modifications to the tetrazolium dye procedure giving improved sensitivity and reliability. Journal of immunological methods 1986; 89(9): 271-277.

11. Takac P, Kello M, Pilatova MB, Kudlickova Z, Vilkova M, Slepcikova P, Petik P, Mojzis J. New chalcone derivative exhibits antiproliferative potential by inducing G2/M cell cycle arrest, mitochondrialmediated apoptosis and modulation of MAPK signalling pathway. Chemico-biological interactions 2018; 292: 37-49.

12. Gerke V, Moss SE. Annexins: from structure to function. Physiological reviews 2002; 82(2): 331-371.

13. Ghavami G, Sardari S, Shokrgozar MA. Cheminformatics-based selection and synergism of herbal extracts with anticancer agents on drug resistance tumor cells-ACHN and A2780/cp cell lines. Computers in biology and medicine 2011; 41(8): 665-674.

14. Chen MF, Yang CM, Su CM, Hu ML. Vitamin C protects against cisplatin-induced nephrotoxicity and damage without reducing its effectiveness in C57BL/6 mice xenografted with Lewis lung carcinoma. Nutrition and cancer 2014; 66(7): 1085-1091.

15. De Martinis BS, Bianchi MD. Effect of vitamin C supplementation against cisplatin-induced toxicity and oxidative DNA damage in rats. Pharmacological research 2001; 44(4): 317-320.

16. Tarladacalisir YT, Kanter M, Uygun M. Protective effects of vitamin $\mathrm{C}$ on cisplatin-induced renal damage: a light and electron microscopic study. Renal failure 2008; 30(1): 1-8.

17. Ajith TA, Usha S, Nivitha V. Ascorbic acid and alphatocopherol protect anticancer drug cisplatin induced nephrotoxicity in mice: a comparative study. Clinica chimica acta 2007 ; 375(1-2): 82-86. 